\title{
INFEKSI Chlamydia trachomatis PADA SALURAN GENITAL, TUBA FALLOPI DAN SERVIKS
}

\author{
St. Aisyah S ${ }^{1}$, Sabilla Suryaning Amanda ${ }^{1}$ \\ ${ }^{1}$ Jurusan Biologi UIN Alauddin Makassar \\ E-mail : aisyahsijid@gmail.com
}

\begin{abstract}
Chlamydia trachomatis is one of the bacteria that can cause sexually transmitted infections (STIs) in both women and men. The subclinical form of Chlamydia trachomatis infection in the upper genital tract often arises with a lack of early detection and treatment and the course of the disease produces acute and chronic infections that can lead to ectopic pregnancy and infertility. This review shows infections that occur in the genital tract, fallopian tubes and cervix caused by Chlamydia trachomatis. From previous studies it was found that Chlamydia trachomatis very quickly causes infection in the genital tract, fallopian tubes and cervix obtained from the test results using the PCR method of endocervical swabs. The condition of the fallopian tube is evaluated during laparoscopy. However, this examination has a long period of time so laboratory tests with different methods can be used together, so there will be better sensitivity and specificity.
\end{abstract}

Keywords: Chlamydia trachomatis, Genital tract, Fallopian tube, Cervix

\section{PENDAHULUAN}

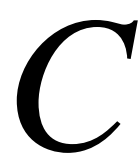

hlamydia trachomatis (CT) adalah salah satu penyebab infeksi genital. tidak spesifik pada pria dan wanita. Infeksi CT adalah salah satu bentuk paling umum dari infeksi menular seksual di dunia. World Health Organization (WHO) memperkirakan bahwa sebanyak 89 juta kasus baru terjadi pada tahun 2001. Prevalensi infeksi CT di Indonesia di antara pekerja seks komersial cukup tinggi, berkisar antara 20-34\% (Karyadi, 1996).

Chlamydia trakomatis adalah mikroorganisme intraseluler obligat yang memiliki dinding sel yang sama dengan bakteri gram negatif. Chlamydia trakomatis diklasifikasikan sebagai bakteri yang mengandung asam deoksiribonukleat (DNA) dan asam ribonukleat (RNA), mereka membelah dengan fusi biner, tetapi seperti virus, mereka berkembang secara intraseluler. atau uretra ke atas, dan infeksi klamidia dapat menyebabkan "cacat" yang serius, karena infeksi klamidia yang meninggi pada saluran genital dapat menyebabkan kolonisasi bakteri di mukosa endometrium dan tuba fallopia (Hendry, dkk., 2013).

Chlamydia trakomatis adalah bakteri intraseluler yang menyebabkan infeksi yang ditularkan melalui kontak seksual. Secara umum semua wanita yang aktif secara seksual berisiko terkena infeksi. Sekitar 60\% -80\% infeksi Chlamydia trakomatis pada wanita tidak menunjukkan gejala sehingga sulit untuk menilai penyebarannya, pasien tidak menyadari infeksi ini dan tidak segera mendapatkan perawatan (Baud, et. al., 2011). 
Infeksi Chlamydia trakomatis sulit untuk didiagnosis, mudah menjadi kronis dan residual, dan dapat menyebabkan berbagai komplikasi serius. Infeksi ini yang tidak diobati dapat menyebabkan masalah kesehatan yang serius, baik pada pria dan wanita, serta untuk bayi yang lahir dari ibu yang terinfeksi (Lanjouw, et. al., 2015).

Kontak langsung dengan Chlamydia Trachomatis dalam keadaan tertentu akan menyebabkan peradangan konjungtiva yang disebut Trachoma. Infeksi pada tahap awal memberikan manifestasi yang sangat bervariasi yang biasanya mirip dengan konjungtivitis kronis pada umumnya, yaitu mata merah, gatal, eksudasi dan pembengkakan pada kelopak mata. Di folikel tarsus atas dan hipertrofi papiler diperoleh. Selama perjalanan penyakit, folikel akan pecah (folikel di Trachoma memiliki sifat rapuh) dan menyebabkan terjadinya jadingan parut (Frich, et. al., 2006).

Dari $100 \%$ wanita yang terinfeksi chlamydia hampir $70 \%$ wanita tidak menyadari dan tidak merasakan gejala apapun baik rasa sakit maupun gejala fisik, hanya saja dapat ditemukan saat dilakukan pemeriksaan di daerah serviks. Pada infeksi chlamydia pada fase awal terjadi di serviks atau uretra. Pada fase awal timbul beberapa keluhan yaitu urin yang abnormal disertai rasa terbakar saat melakukan buang air kecil. (Johnson, et.. all)

Gejala tunggal pada infeksi chlamydia yaituterjadi perdarahan setelah melakukan kontak seksual serta terjadi perdarahan pada siklus menstruasi yang tidak sesuai dengan siklus yang seharusnya yaitu terjadi perdarahan di pertengahan siklus menstruasi juga merupakan gejala tunggal infeksi dari infeksi chlamydia. Infeksi tunggal ini dapat dilakukan dengan pemeriksaan venereologik serviks dimana pemeriksaan venereologik dapat menyebabkan perdarahan saat dilakukan kerokan atau apusan dengan spatula. Secara medis gejala dan tanda yang dapat diketahui dari infeksi Chlamydia sangat sulit dibedakan dengan infeksi genital lainnya (Miller, 2006).

Berdasarkan penelitian yang telah dilakukan oleh Arti (2011) dengan hasil manifestasi klinis pada pemeriksaan klinis folikel dan hipertrofi papiler diperoleh di tarsus atas, pannus, lubang Herbert, entropion, trichiasis, atau cicricion di tarsus atas. Mac Callan, mengklasifikasikan trachoma berdasarkan gambaran klinis, menjadi 4 tahap, yaitu stadium I yang disebut sebagai tahap awal atau tahap. Di tarsus superior terlihat hipertrofi papiler dan folikel folikel yang belum dimasak. Stadium II yang disebut tahap mapan atau panggung nyata. Dimana folikel dan papula diperoleh di tarsus superior. Tahap ini selanjutnya dibagi menjadi dua, yaitu IIA dan IIB. Stadium III mulai terbentuk jaringan parut atau sikat pada konjungtiva tarsal superior dalam bentuk garis putih halus. Pada tahap ini masih ada folikel di konjungtiva tarsal superior dan pannus aktif muncul. Stadium IV Disebut juga trachoma yang disembuhkan. Pada tahap ini konjungtiva tarsal superior tidak lagi ditemukan di folikel, hanya krikrik dan pannus yang tidak lagi aktif. Pada tahap ini juga dapat ditemukan komplikasi komplikasi dari trachoma.

Berdasarkan penelitian yang dilakukan oleh Wafirotus dan Relly (2015) mengenai infeksi Chlamydia trakomatis. Infeksi Chlamydia trakomatis diperiksa menggunakan metode PCR dari endapan serviks dan Chlamydia trakomatis IgG diperiksa menggunakan metode ELISA dari darah vena. Kondisi tuba falopi dievaluasi selama laparoskopi. Dengan hasil yang didapatkan bahwa sebagian besar tuba fallopi pada subjek dengan infeksi Chlamydia trakomatis menunjukkan kerusakan, ditandai oleh adhesi perituba, oklusi tuba, fimbria phimosis atau hidrosalping selama laparoskopi. IgG Chlamydia trakomatis berbeda secara signifikan dari kerusakan tuba fallopi sedangkan endometriosis dan riwayat operasi sebagai faktor risiko tidak menunjukkan 
perbedaan yang signifikan. Angka kejadian infeksi Chlamydia trakomatis pada wanita infertil cukup tinggi. Pemeriksaan IgG Chlamydia trakomatis dapat menjadi penanda adanya kerusakan tuba fallopi. Karakteristik sampel penelitian dilakukan berdasarkan tabel berikut:

Tabel 1. Karakteristik Sampel Penelitian

\begin{tabular}{lcc}
\hline \multicolumn{1}{c}{ Karakteristik } & Frekuensi & Persentase \\
\hline Usia & 9 & \\
$25-30$ tahun & 25 & $21,42 \%$ \\
$30-35$ tahun & 8 & $59,52 \%$ \\
$>35$ tahun & & $19,04 \%$ \\
\hline Lama infertilitas & 15 & $35,71 \%$ \\
$1-3$ tahun & 12 & $28,57 \%$ \\
$3-5$ tahun & 15 & $35,71 \%$ \\
$>5$ tahun & & \\
\hline Keluhan penyerta & 9 & $21,42 \%$ \\
Dismenorea & 1 & $2,38 \%$ \\
Nyeri panggul & 5 & $11,90 \%$ \\
Keputihan & 2 & $4,76 \%$ \\
Perdarahan & 4 & $9,52 \%$ \\
Dismenorea + nyeri panggul + dispareuni & 1 & $2,38 \%$ \\
Dismenorea + nyeri panggul + keputihan & 1 & $2,38 \%$ \\
Dismenorea + keputihan & 17 & $40,47 \%$ \\
Tidak ada keluhan & & \\
\hline Temuan laparoskopi & 9 & $21,42 \%$ \\
Perlekatan perituba & 6 & $14,28 \%$ \\
Fimosis fimbria & 15 & $35,71 \%$ \\
Oklusi tuba & 2 & $4,76 \%$ \\
Hidrosalping & 23 & $54,76 \%$ \\
Endometriosis & 9 & $21,42 \%$ \\
\hline Mioma uteri & 3 & $7,14 \%$ \\
Tanda Fitz-Hugh-Curtis & 5 & $11,90 \%$ \\
Normal pelvis & &
\end{tabular}

Berdasarkan penelitian yang telah dilakukan oleh Hendri (2013), dengan penelitian mengenai infeksi chlamydia di serviks dan tuba pada pasien kehamilan ektopik yang dilakukan di RSUP menunjukkan hasil bahwa pada penelitian ini pasien yang diteliti adalah pasien yang mengalami kehamilan ektopik. Dimana kehamilan ektokpik adalah kehamilan yang terjadi diluar Rahim. Penelitian ini dilakukan dengan pengambilan spesimen endoserviks lalu dilakukan operasi laparatomi atau laparaskopi untuk diambil spesimen pada serviks dan tuba selanjutnya dilakukan pemeriksaan PCR yang menjadi penentu untuk infeksi Chlamydia trakomatis. Dimana penelitian ini menghasilkan hasil bahwa didapatkan angka kejadian infeksi Klamidia trakomatis di serviks dan tuba pada pasien kehamilan ektopik terganggu adalah 36\% (9/25) dan 12\% (3/25). Dari hasil anamnesis dan pemeriksaan fisik saat datang, didapatkan kecenderungan peningkatan risiko infeksi Klamidia trakomatis pada rentang usia menikah antara 20-35 tahun sekitar 64\% (16 penderita dari total sampel 25 penderita), adanya riwayat keputihan sekitar $72 \%$ (18 penderita dari total sampel 25 penderita), dan adanya riwayat infeksi saluran kemih/panggul sekitar 56\% (14 penderita dari total sampel 25 penderita). Walaupun secara statistik didapatkan tidak bermakna. Reaksi 
imun tubuh tersebut diperkirakan dapat memicu terjadinya reaksi silang, sehingga dapat menimbulkan kerusakan tanpa kehadiran langsung klamidia pada tuba. Meski demikian dengan hanya ditemukaannya infeksi klamidia pada 12 kasus dari 25 kasus kehamilan ektopik, maka perlu dipikirkan kemungkinan adanya penyebab lain dari kehamilan ektopik di luar infeksi klamidia.

\section{KESIMPULAN}

Chlamydia trakomatis adalah salah satu bakteri yang dapat menyebabkan penyakit infeksi menular seksual yang sangat berbahaya bagi kesehatan baik pria maupun wanita serta akan menganggu janin pada ibu hamil. Pemeriksaan ini dapat dilakukan dengan berbagai cara yaitu dengan metode PCR dan laparoskopi. Infeksi Chlamydia trachomatis memiliki peranan sebagai faktor risiko terjadinya kerusakan pada tuba fallopi. Penanda adanya infeksi berupa pemeriksaan imunoglobulin Chlamydia trachomatis dapat membantu memberikan gambaran mengenai kondisi tuba fallopi pada wanita dengan infertilitas.

\section{DAFTAR PUSTAKA}

Arti, K. (2011). TRACHOMA. Jurnal Kedokteran Syiah Kuala, 11(2A), 89-95.

Baud D, Goy G, Jaton K, Osterheld MC, Blumer S, Borel N, Vial Y, et al. (2011). Role of Chlamydia trachomatis in Miscarriage. Emerging Infectious Diseases, 17(9), 630-635.

Frick KD, Hanson CL, Jacobson GA. (2006). Global Burden Of Trachoma And Economic Of The Disease. Am J Trop Med Hyg, 69, 1-10.

Karyadini HW. (1996). Uji diagnostik pemeriksaan klinis, gram dan giemsa terhadap PCR untuk deteksi, C. trachomatis pada pekerja seks komersial. [Tesis]. Semarang: Kesehatan Bagian Ilmu Kulit dan Kelamin Universitas Diponegoro.

Lanjouw E, Ouburg S, Vries HJ, Stary A, Radcliffe K, Unemo M. (2015). European guideline on the management of Chlamydia trachomatis infections. International Journal of STD \& AIDS, 2, 1-16.

Wafirotus, S., Relly Y. (2015). Tingginya Infeksi Chlamydia trachomatis pada Kerusakan Tuba Fallopi Wanita Infertil. Majalah Obstetri \& Ginekologi , 23(2), 69-74.

Miller, KE. (2006). Diagnosis and treatment of Chlamydia trachomatis infection. Am Fam Physician, 73, $1411-6$.

Johnson RE, Newhall WJ, JR, JS. (2002). Papp Knapp Black Gift Screening tests to detect CM, TL. Chlamydia trachomatis and Neisseria gonorrhoeae infections, 51(15), 1-38.

Hendri, A., Henri, S., Fidel. (2013). Kejadian infeksi Klamidia trakomatis di serviks dan tuba pada pasien kehamilan ektopik terganggu di RSUP H. Adam Malik Medan dan RS Jejaring FK USU. Majalah Kedokteran Nusantara, 46(2), 65-69. 